\title{
HUBUNGAN ANTARA USIA DAN TINGKAT PENDIDIKAN DENGAN TINGKAT PENGETAHUAN IBU HAMIL TENTANG PERAWATAN PAYUDARA SELAMA HAMIL DI POLI KANDUNGAN DI RSU JASEM, SIDOARJO
}

\author{
Agus Sulistyowati ${ }^{1 *}$, Kusuma Wijaya Ridi Putra ${ }^{1}$, Riza Umami ${ }^{1}$ \\ ${ }^{1}$ Akademi Keperawatan Kerta Cendekia Sidoarjo \\ *Correspondence: \\ Agus Sulistyowati \\ Email: agussulistyowati78@gmail.com
}

\begin{abstract}
Background: Perawatan payudara merupakan kebutuhan perawatan diri yang diperlukan untuk meningkatkan kesehatan terutama pada ibu hamil. Fenomena yang terjadi poli kandungan di RSU Jasem Sidoarjo. Banyak ibu yang merawat payudaranya selama hamil tidak terawat dengan baik dan benar, sebagian besar para ibu saat hamil tidak melakukan perawatan payudaranya, tujuan penelitian ini adalah untuk mengetahui tingkat pengetahuan ibu hamil tentang perawatan payudara selama hamil.

Purpose: Penelitian ini bertujuan untuk mengetahui hubungan antara usia dan tingkat pendidikan dengan tingkat pengetahuan Ibu Hamil tentang perawatan payudara selama hamil.

Method: Metode penelitian yang digunakan adalah deskriptif. Populasi dalam penelitian ini berjumlah 30 Responden sampel sebanyak 30 responden diambil dengan teknik sampling quota sampling teknik pengumpulan data menggunakan kuesioner jenis close-ended questionnaire dengan jumlah pertanyaan sebanyak 10 soal. Setelah data terkumpulkan dilakukan Uji statistik Pearson's product moment correlation dengan menggunakan SPSS 21.

Results: Terdapat hubungan yang positif antara usia dan tingkat pendidikan dengan tingkat pengetahuan ibu hamil tentang perawatan payudara selama hamil ( $r=.564, p<.01 ; r=.560, p<.01$, secara berurutan).

Conclusion: Dari hasil penelitian tersebut disimpulkan hubungan yang positif antara pertambahan usia dan tingkat pendidikan dengan tingkat pengetahuan ibu hamil tentang perawatan payudara selama hamil.
\end{abstract}

Key words: usia, tingkat pendidikan, tingkat pengetahuan, perawatan payudara, Ibu Hamil

\section{PENDAHULUAN}

Perawatan payudara adalah usaha untuk melancarkan ASI dan mencegah masalah-masalah yang muncul pada saat menyusui seperti susu nyeri atau lecet, payudara bengkak dan saluran susu tersumbat (Anwar, 2005; Nurhati, 2009).

Berdasarkan laporan dari survei demografi dan kesehatan Indonesia (Kementerian Kesehatan Republik Indonesia [Kemenkes RI], 2011), di usia lebih dari 25 tahun sepertiga wanita di dunia (38\%) didapati tidak menyusui bayinya karena terjadi pembengkakan payudara, dan di Indonesia angka cakupan ASI eksklusif mencapai 32,3\% ibu yang memberikan ASI eksklusif pada anak mereka. Survei demografi dan nasehat indoneia (SDKI) tahun 2008-2009 menunjukkan bahwa $55 \%$ ibu menyusui mengalami mastitis dan puting susu lecet, kemungkinan hal tersebut disebabkan 
karena kurangnya perawatan payudara selama kehamilan.

Ibu yang tidak mengetahui perawatan payudara biasanya karena mereka kurangnya pengetahuan, kurangnya pengetahuan itu sendiri di pengaruhi oleh beberapa faktor di antaranya rendahnya pendidikan serta kurangnya informasi diantaranya membaca buku, menonton televisi tentang kesehatan, dan tidak aktif dalam mengikuti penyuluhan kesehatan tentang perawatan payudara. Dan akibatnya bayi pun tidak mau menyusui atau minum ASI ibunya, padahal pemberian ASI merupakan metode pemberian makanan yang terbaik, terutama pada bayi pada umur kurang dari 6 bulan, selain itu juga bermanfaat bagi ibu (Melltyna, 2003; Varney, 2007).

Untuk mengatasi masalah tersebut salah satunya adalah memberikan pengarahan tentang perawatan payudara pada ibu hamil sedini mungkin, melakukan health aducation dengan bekerja sama dengan bidan setempat melalui penyuluhan, penyuluhan pada ibu hamil yang di sertai demonstrasi cara perawatan payudara sebelum dan setelah melahirkan dengan benar, serta peragaan tentang perawatan payudara pada saat kontrol kehamilan dan kunjungan masa nifas, dimana penyuluhan tepat pada waktu ibu mengembangkan kemampuan dalam mengambil keputusan yang merupakan informasi keterpaduan menalar ilmiah dan sistematis (Anwar, 2005; Suririnah, 2008). Selain itu juga bisa melalaui leaflet, alat peraga, poster-poster dan promosi melalui radio dan media lainnya. upaya ini dapat meningkatkan kemampuan ibu dalam perawatan payudara secara baik dan benar sebagai upaya preventif terhadap masalah menyusui sehingga proses menyusui dapat berjalan dengan lancar dan merupakan upaya untuk meningkatkan derajat kesehatan ibu dan bayi (Saryono dan Pramitasari, 2009).

\section{METODE DAN BAHAN}

Dalam penelitian ini, desain yang digunakan adalah penelitian crosssectional, dimana peneliti ingin mengetahui hubungan tingkat pendidikan dan usia dengan tingkat pengetahuan ibu hamil tentang perawatan payudara selama hamil di poli kandungan di RSU Jasem, Sidoarjo. Dalam penelitian ini, pengambilan sampel dilakukan secara incidental sampling, yaitu semua ibu hamil yang datang di poli kandungan RSU Jasem, Sidoarjo. Jumlah sampel yang digunakan dalam penelitian ini adalah 30 responden.

Instrument penelitian yang digunakan dalam pengumpulan data pada penelitian ini adalah dengan menggunakan Close-ended Questionnaire yang berupa kuesioner demografi dan kuesioner tingkat pengetahuan dengan jumlah 10 nomor. Saat akan melakukan penelitian, peneliti minta surat pengantar dari institusi untuk diberikan kepada pihak RSU Jasem untuk dilakukannya penelitian. Sebelum diberi kuesioner, responden diberi penjelasan terlebih dahulu tentang cara pengisian kuesioner. Pembagian kuesioner dilakukan secara langsung oleh peneliti, selanjutnya responden mengisi informed consent yang menyatakan bersedia menjadi responden dalam penelitian yang dilakukan. Setelah itu, responden diberikan kesempatan untuk menjawab semua pertanyaan yang ada di kuesioner yang telah disiapkan. Data yang terkumpul melalui kuesioner kemudian di tabulasi dan dilakukan pengolahan dengan menggunakan SPSS 21. Uji statistik yang 
dipergunakan dalam penelitian ini adalah Pearson's product moment correlation.

\section{HASIL PENELITIAN}

Hubungan antara Usia dan Tingkat Pendidikan dengan Tingkat Pengetahuan Ibu Hamil Tentang Perawatan Payudara Selama Hamil di Poli Kandungan di RSU Jasem, Sidoarjo dapat dilihat dalam tabel 1 sebagai berikut.

Tabel 1. Hubungan antara usia dan tingkat Pendidikan dengan tingkat pengetahuan ibu hamil tentang perawatan payudara selama hamil di poli kandungan RSU Jasem, Sidoarjo pada bulan April 2015.

\begin{tabular}{ccc}
\hline & Usia & $\begin{array}{c}\text { Tingkat } \\
\text { Pendidikan }\end{array}$ \\
\hline $\begin{array}{c}\text { Tingkat } \\
\text { Pengetahuan }\end{array}$ & $.564^{* *}$ & $.560^{* *}$ \\
\hline$* * p<.01$ & & \\
\hline
\end{tabular}

Berdasarkan data pada tabel 1 didapatkan bahwa terdapat hubungan yang positif antara usia dan tingkat pendidikan dengan tingkat pengetahuan ibu hamil tentang perawatan payudara selama hamil $(r=.564, p<.01 ; r=.560, p<.01$, secara berurutan).

\section{PEMBAHASAN}

Berdasarkan hasil penelitian didapatkan bahwa adanya hubungan yang positif antara usia dengan tingkat pengetahuan seorang ibu tentang perawatan payudara selama hamil $(r=.564, p<.01)$. Hal tersebut menggambarkan bahwa semakin tua usia dari responden maka dia akan mempunyai tingkat pengetahuan yang semakin baik. Hal tersebut dikarenakan semakin tua semakin bijaksana, semakin banyak informasi dan pengetahuan. Usia berpengaruh terhadap daya tangkap dan pola pikir seseorang. Semakin bertambah usia akan berkembang pula daya tangkap dan pola pikirnya, sehingga pengetahuan yang di perolehnya semakin membaik. Menurut Nursalam (2008), usia dapat mempengaruhi pengetahuan seseorang, semakin cukup umur, tingkat kematangan dan kekuatan akan lebih matang dalam berfikir dan bekerja.

Sama halnya dengan tingkat pendidikan. Pada tingkat pendidikan juga didapatkan hasil bahwa ada hubungan yang positif dengan tingkat pengetahuan ibu hamil tentang perawatan payudara selama hamil $(r=.560, p<.01)$. Hal tersebut menunjukkan bahwa semakin tinggi tingkat pendidikan seseorang akan mempengaruhi tingkat pengetahuan dan pemahaman terhadap sesuatu hal. Tingkat pendidikan erat kaitanya dengan tingkat pengetahuan seseorang tapi tidak berlaku apabila orang tersebut lebih aktif mencari informasi tentang perawatan payudara selama hamil, namun semakin tinggi tingkat pendidikan maka semakin tinggi tingkat pendidikannya maka semakin tinggi pula pengetahuan. Tingkat pendidikan yang tinggi maka seseorang akan cenderung untuk mendapatkan informasi, baik dari orang lain maupun media massa (Nursalam, 2008; Serrano-Gil dan Jacob, 2010). Semakin banyk informasi yang masuk, semakin banyak pula pengetahuan yang didapat tentang kesehatan. Pengetahuan sangat erat kaitanya dengan pendidikan baik formal maupun non-formal, dimana diharapkan seseorang dengan pendidikan tinggi, maka orang tersebut akan semakin luas pula pengetahuannya. Namun sebaliknya, jika tingkat pendidikannya rendah akan menghambat perkembangan tentang seseorang terhadap penerimaan informasi dan nilai - nilai yang baru diperkenalkan. 
SIMPULAN

Hasil penelitian tersebut disimpulkan bahwa dengan pertambahan usia dan semakin tinggi tingkat pendidikan maka semakin tinggi pula tingkat pengetahuan ibu hamil tentang perawatan payudara selama hamil.

\section{SARAN}

Diharapkan dengan adanya hasil penelitian ini dapat dijadikan sebagai bahan masukan kepada petugas pelayanan kesehatan dalam memberikan penyuluhan dapat memperhatikan faktor usia dan tingkat pengetahuan sehingga materi yang disampaikan dapat diterima dengan baik oleh peserta penyuluhan.

\section{DAFTAR PUSTAKA}

1. Anwar. 2005. Cara Perawatan Payudara. Jakarta: Salemba Medika.

2. Nurhati, M. 2009. Kehamilan dan Persiapan Persalinan. Jakarta: Garamond.

3. Kementerian Kesehatan Republik Indonesia. 2011. Profil Kesehatan Indonesia Tahun 2010. Jakarta: Kementerian Kesehatan Republik Indonesia.

4. Melltyna. 2003. Keperawatan Maternitas. Jakarta: EGC.

5. Varney, H. 2007. Asuhan Kebidanan. Jakarta: EGC.

6. Suririna. 2008. Buku Pintar Kehamilan dan Persalinan. Jakarta: Gamedia Pustaka Utama.

7. Saryono, dan Pramitasari, R. D. 2009. Perawatan Payudara. Yogyakarta: Mitra Cendikia Offset.

8. Nursalam. 2008. Konsep Dan Penerapan Metodologi Penelitian Ilmu Keperawatan. Jakarta: Salemba Medika.
9. Serrano-Gil M, Jacob S. 2010. Engaging and empowering patients to manage their type 2 diabetes, Part I: a knowledge, attitude, and practice gap? Advances in therapy. 27(6):321-333. 